\title{
Sustainable Community Empowerment Efforts Through the Development of Small and Medium Enterprises of Eceng Gondok
}

\author{
Andi Tenri Sompa ${ }^{1 *}$ Riduansyah Syafari ${ }^{2}$ M. Najeri Al Syahrin ${ }^{1}$ \\ ${ }^{1}$ Governmental Science, Lambung Mangkurat University, Banjarmasin, Indonesia \\ ${ }^{2}$ Public Administration, Lambung Mangkurat University, Banjarmasin, Indonesia \\ "Corresponding author.Email: tenri@ulm.ac.id
}

\begin{abstract}
The issue of community empowerment is the concern of the local government. Community empowerment is carried out to create a democratic, prosperous, and advanced society. One of the patterns of empowerment efforts is by carrying out sustainable community empowerment by developing small and medium-sized community businesses that utilize Eceng Gondok. Eceng Gondok is an aquatic plant that grows wild and has the potential to damage the ecosystem. This article aims to describe sustainable community empowerment by developing small and medium-sized community businesses that utilize Eceng Gondok in Amuntai Tengah District. The articles' preparation was based on community service results, which was carried out in December 2019 and January 2020. In increasing the discussion, literature studies were carried out from various sources of literature and journals. The discussion results describe the Eceng Gondok UMKM in Amuntai Tengah District as a pioneer UMKM in Hulu Sungai Utara Regency. In improving the competence of UMKM players, Hulu Sungai Utara Regency's local government conducts training activities for making innovative Eceng Gondok products. Training is carried out by increasing cooperation with related agencies, Department of Industry, Office of Agriculture, Bappeda and Sekda Hulu Sungai Utara district. Based on routine training activities carried out by the Local Government of Hulu Sungai Utara Regency, the community has increased income due to the sale of Eceng Gondok handicraft products.
\end{abstract}

Keywords: community, empowerment, Small and Medium Enterprises (UMKM), Eceng Gondok

\section{INTRODUCTION}

Empowerment is a form of all efforts to empower a person or society from their disabilities [1]. Empowerment is intended to create a just, democratic, prosperous, and advanced society [2,3]. Community empowerment can be realized if the fundamental role of the government is obtained. This is because the community must be helped to get out of disability. The government's role in protecting, guiding, and empowering the community can improve the economy [4]. In particular, increasing the community's economy can be done by implementing a people's economy, manifested in Small and Medium Enterprises (UMKM).

There are three main factors in empowerment, namely 1 ). They are growing a business climate, 2). Strengthening the potential that is owned, and 3). Protecting Community Business. In an excellent economic system, people are more independent in meeting their needs. Through this method, not only will independence directly change the ability or skills of the community to become more professional, which will lead to the creation of social welfare [5,6]. Law Number 20 of 2008 concerning Small and Medium Enterprises (UMKM), article 2 states that the business world aims to build a national economy based on just economic democracy. The government even needs to provide infrastructure and land for the business community. The creative industry sector becomes Regional Original Income (PAD) and is no longer adopted in giant business actors' eyes [7,8].

Existence UMKM can become stabilizers and dynamists of the Indonesian economy. As a developing country, Indonesia is significant to pay attention to UMKM because UMKM has better performance in a productive workforce, increases high productivity, and can live on the sidelines of large businesses [9]. UMKM can support large businesses, such as providing materials, spare parts, and other supporting materials. UMKM can become the spearhead for large businesses in distributing and selling products from large businesses to consumers. The position of this UMKM is getting stronger. Apart from absorbing quite a lot of workforce, these UMKM are agile, so they can survive in unfavorable conditions, such as the current global crisis. Generally, UMKM have a strategy by making unique and superior products to not compete with products from big businesses [10].

The factual existence of UMKM in improving the economy and empowering communities can be found simultaneously in Hulu Sungai Utara District, Amuntai 
Tengah District. Hulu Sungai Utara District mostly consists of lowlands inundated by swamps, either monotone or periodically inundated. Approximately $89 \%$ is swampland, and most of it has not been utilized optimally. These swamps are mostly overgrown by Eceng Gondoks, which become weeds (nuisance plants) for other aquatic plants. The residual use of chemical fertilizers by farmers in the rice fields is then washed away into the river, making the growth and spread of Eceng Gondok very quickly, making it difficult to handle, even to the point of jamming river traffic. Many potentials can be extracted from the existence of Eceng Gondok, including being used as handicraft materials such as bags and others. It's just that this requires special skills that are not easy for everyone. This article aims to describe sustainable community empowerment by developing small and medium-sized enterprises that use Eceng Gondok as a handicraft product.

\section{METHOD}

Community service activities were carried out by Amuntai Tengah District on December 17-21, 2019, and January 911, 2020. A series of activities were carried out with socialization, focus group discussions, and training. However, to sharpen the results of activities carried out the literature review. A literature study is understood as a theoretical study based on references, books, related journals to describe the development of small and medium enterprises in the community that utilize Eceng Gondok in the Amuntai Tengah District. Literature review using books and journals. The article is descriptive by using a structured narrative $[11,12]$. However, in addition to literature studies, this article uses the author's empirical approach. Thus it is expected that ideas are rational and formed by individuals through experience $[13,14]$.

\section{RESULTS AND DISCUSSION}

The Eceng Gondok handicraft business was founded in 2005 by a family, followed by the local community. In the Amuntai Tengah sub-district itself, there are currently only two UMKM, namely Kayuh Baimbai and UMKM Gawi Manuntung, which process Eceng Gondok as the primary material for making its products. Armed with the knowledge of eceng gondok and furniture training that he got from the Office of Cooperatives, UMKM, Industry, and Trade (Diskuperindag) of Hulu Sungai Utara Regency, plus information from the media about the use of Eceng Gondok, he gave rise to the idea to start using Eceng Gondok raw materials to make various forms of handicrafts.

The stages of making Eceng Gondok handicraft products begin with the selection of essential ingredients. The standard length of ordinary Eceng Gondok stems is between $45-50 \mathrm{~cm}$, while the super ones are $50-60 \mathrm{~cm}$ long. To prepare Eceng Gondok for plaiting, clean it with well water to remove dirt on the leaves and stems of the water. When you remove Eceng Gondok from the water (where it grows), other parts of the plant are carried away as well, such as flowers, leaves, stems, shoots, and roots.
Therefore, only the petiole is needed to prepare the woven material, so the other part must be set aside. After the parts that are not needed are set aside, the Eceng Gondok stalk can then be washed and rinsed until it is spotless.

After the Eceng Gondok stalk is clean of all dirt, it can be dried in the sun, occasionally turning it over until the stalk is dehydrated. Drying time is approximately six days or depending on the stalk's thickness and the weather (whether there is sunlight). Stalks should be dried on the cement floor or the sand. Because drying in this way, the results will be maximized (dry evenly). Efforts can be made to help separate the water content before drying it in the sun. When it dry is pressed directly with a manual press and then dried in the sun.

After drying, press the Eceng Gondok and then weave it to get $50-60 \mathrm{~cm}$ sheets of Eceng Gondok. There are several ways of watering the weaving change during weaving, namely: 1) the ends or bases are clamped with wooden tongs or nailed, 2) Ribbons with odd numbers are pulled to the left, while ribbons with an even number are pulled to the right, and 4) placing one piece of ribbon between the odd-numbered warp, with the weave numbered type of woven motif, those who have made basic weaving will immediately be able to do it well. Henceforth, it can be modified to produce other motifs that are unique, beautiful, and charming. The following are the results of a Eceng Gondok-based product.

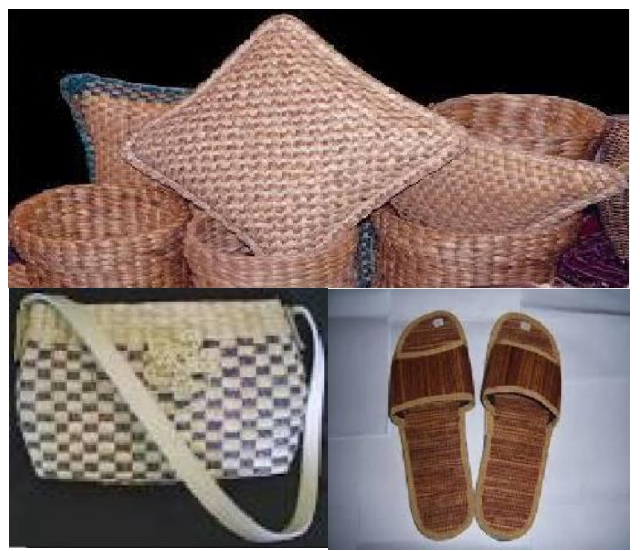

Figure 1 Eceng Gondok Craft Product

Micro, Small, and Medium Enterprises are always interesting to study, not only from the aspect of resilience, financing, obtaining loans, or from a business managerial aspect. In the era of globalization, especially with the existence of economic integration in Southeast Asia, namely the economic unification (Economic Union), which makes Southeast Asia into an economic community with a single production base, UMKM must be able to maintain their existence amid the onslaught of the global economy $[15,16]$.

Hulu Sungai Utara Regency and related agencies, namely the Department of Industry, the Department of Agriculture, Bappeda, and the Regional Secretary of Hulu Sungai Utara Regency. This support is because the Eceng Gondok UMKM community's empowerment is in line 
with the Hulu Sungai Utara district government program, namely maximizing the potential of natural resources for the welfare of the people. UMKM still think that branding is limited to creating logos, distinctive colors, distinctive objects (hats, clothes, etc.), and / or writing identities. This opinion is not wrong, but rather, branding is a symbol of products, services, and companies, even oneself. The question is, how important will it be for UMKM to build their product, service, and business brands? Conceptually and the reality on the ground, it seems that building a brand is very important and fundamental.

However, the obstacles faced are, in general, UMKM in Hulu Sungai Utara Regency does not have business legality, which makes it difficult for them to access banks and other financial institutions [17]. Besides, UMKM are often in a weak bargaining position when legal problems arise [18]. For this reason, UMKM need to be made aware of the importance of ownership of business legality. An industrial business license is mandatory if our business has a capital of more than Rp. 5 million to Rp. 200 million. We can apply for an industrial business permit at the Integrated Licensing Service of Hulu Sungai Utara Regency. Meanwhile, if the business has developed and includes large businesses, it can apply to the Integrated Licensing Service of South Kalimantan Province or BKPM when it reaches the national level. As for the Business classification of Micro, Small and Medium based on Law no. 20 of 2008 concerning UMKM:

Table 1 The classification of UMKM is based on Law no. 20/2008

\begin{tabular}{|c|c|c|}
\hline Size of Business & Asset & Turnover \\
\hline Microbusiness & Minimum 50 million & A maximum of 300 million \\
\hline Small business & $>50$ million - 500 million & Maximum 3 billion \\
\hline Medium Enterprises & $>500$ Million - 10 Billion & $>2.5-50$ billion \\
\hline
\end{tabular}

What is meant by net assets is the result of a reduction in the total value of business assets (assets) from the total value of liabilities, excluding land and buildings for business premises. This problem did not make the government standstill [19]. The local government stimulates Eceng Gondok UMKM to carry out the branding process. The branding process needs a study. For UMKM that do not yet have more budgets, the first step that can be taken is to introduce a unique value proposition of the goods or services they own. Simply put, in every product (goods or services), a service process is also attached. From this service process activity, UMKM actors can optimize activities and service attributes to create brand value. Thus, the resulting product becomes more expensive.

\section{CONCLUSION}

Hulu Sungai Utara District mostly consists of lowlands inundated by swamps, either monotone or periodically inundated. The swamp is mostly overgrown by Eceng Gondok, which becomes weeds. The potential that can be explored from Eceng Gondok is used as a handicraft material such as bags, sandals, carpets, and others. Therefore, community empowerment is needed, especially in the creative economy (Micro and Small and Medium Enterprises). The existence of UMKM in improving the economy and empowering communities can simultaneously be found in Hulu Sungai Utara District, Amuntai Tengah District. In the Amuntai Tengah subdistrict itself, there are currently only two UMKM, namely, UMKM Kayuh Baimbai and UMKM Gawi Manuntung, which process Eceng Gondok as the primary material for making its products-armed with the knowledge of eceng gondok and furniture training that he got from the HSU Office of Cooperatives, UMKM, Industry, and Trade (Diskuperindag). In increasing the selling value of government handicraft products, HSU has stimulated Eceng Gondok UMKM to carry out the branding process. Thus, the resulting product has a clear identity and has a unique value to offer to the market.

\section{REFERENCES}

[1] P. \& Pranarka, Pemberdayaan Konsep, Kebijakan Dan Implementasi. Jakarta: Rineka Cipta, 1995.

[2] I. R. Adi, Intervensi Komunitas Pengembangan Masyarakat Sebagai Upaya Pemberdayaan Masyarakat. Jakarta: Rajawali Pres, 2009.

[3] M. Moelyono, Menggerakkan Ekonomi Kreatif antara Tuntutan dan Kebutuhan. Jakarta: Raja Grafindo Persada, 2010.

[4] R. Rasyid, Makna Pemerintahan: Tinjauan dari Segi Etika dan Kepemimpinan. Jakarta: Mutiara Sumber Widya, 2000.

[5] Ramdhansyah \& Sondang Aida Silalahi, "PENGEMBANGAN MODEL PENDANAAN UMKM BERDASARKAN PERSEPSI UMKM," J. Keuang. dan Bisnis, vol. 5, no. 1, pp. 30-40, 2013.

[6] Y. R. Suci, "Perkembangan UMKM (Usaha Mikro Kecil Menengah) di Indonesia," J. Ilm. Fak. Ekon., vol. 6, no. 1, pp. 51-58, 2017.

[7] I. P. Ngurah and P. Kartika, "Pengaruh Pendapatan Asli Daerah pada belanja Modal dengan Pertumbuhan Ekonomi sebagai Variabel Pemoderasi," E-Journal Akunt. Univ. Udayana, vol. 1, pp. 79-92, 2014.

[8] A. Fiskhinindya and A. Yunani, "European Journal of Management and Marketing Studies IMPLEMENTATION OF GOOD 


\section{GOVERNANCE PRINCIPLES IN PROCUREMENT OF REGIONAL GOVERNMENT GOODS AND SERVICES BY THE PROCUREMENT SERVICE UNIT ( ULP ) BANJARBARU CITY , INDONESIA,"} Eur. J. Manag. Mark. Stud., vol. 4, no. 1, pp. 68-85, 2019, doi: 10.5281/zenodo.3346013.

[9] R. Sudaryanto, R., \& Wijayanti, Strategi pemberdayaan UMKM menghadapi pasar bebas Asean. Pusat Kebijakan Ekonomi Makro; Badan Kebijakan Fiskal. Jakarta: Kementerian Keuangan, 2013.

[10] D. C. Lantu, M. S. Triady, A. F. Utami, and A. Ghazali, "Pengembangan Model Peningkatan Daya Saing UMKM di Indonesia: Validasi Kuantitatif Model," J. Manaj. Teknol., vol. 15, no. 1, pp. 77-93, 2016, doi: 10.12695/jmt.2016.15.1.6.

[11] B. Rahmanto, Metode Pengajaran Sastra. Yogyakarta: Kanisius, 2004.

[12] S. Nasution, Metode Penelitian Naturalistik Kualitatif. Bandung: Tarsito, 2003.
[13] M. Sarman, Pengantar Metodologi Penelitian Sosial. Banjarmasin: Pustaka FISIP UNLAM, 2004.

[14] S. Suryabrata, Metodologi Penelitian. Yogyakarta: Pustaka Pelajar, 2004.

[15] A. Setyobudi, "Peran Serta Bank Indonesia Dalam Pengembangan Usaha Mikro, Kecil, dan Menengah (UMKM)," Buletin Hukum dan Kebanksentralan, vol. 5, no. 2. pp. 29-35, 2007.

[16] E. Suharto, Membangun Masyarakat Memberdayakan Rakyat. Bandung: Alfabeta, 2010.

[17] Y. T. Keban, Indikator Kinerja Pemerintah Daerah: Pendekatan Manajemen dan Kebijakan. Yogyakarta: Fisip UGM, 1995.

[18] M. R. Pranadjaja, Hubungan Antar Lembaga Pemerintahan. Jakarta: Sinar Grafika, 2003.

[19] A. T. Sompa, "Procurement Mechanism of Goods and Regional Government Services in Accordance with the Principle of Good Governance in Banjarbaru," Rudn J. Polit. Sci., vol. 21, no. 4, pp. 706-717, 2019, doi: 10.22363/2313-1438-2019-21-4-706-717. 